\title{
A SCHOOL-BASED ORAL HEALTH EDUCATIONAL PROGRAM: THE EXPERIENCE OF MARINGA- PR, BRAZIL
}

\author{
PROGRAMA EDUCACIONAL EM SAÚDE BUCAL BASEADO EM ESCOLAS: \\ A EXPERIÊNCIA DE MARINGÁ- PR, BRASIL
}

\author{
Carlos Alberto CONRADO, DDS, PhD \\ Full Professor - Director of the Dental School, State University of Maringa (UEM), Maringa-PR, Brazil. \\ Sandra Mara MACIEL, DDS, PhD \\ Associate Professor - Dental School, Northern University of Parana (UNOPAR), Londrina, PR and State University of Maringa (UEM), \\ Maringa-PR, Brazil.
}

Márcia Regina OLIVEIRA

Dental Practitioner, Cianorte-PR, Brazil.

\begin{abstract}
7 he main purpose of this study was to evaluate the preliminary results of a school-based oral health educational strategy adopted in public primary schools from the city of Maringa, State of Parana, Brazil. The study sample was composed by 556 children and adolescents aged 6 to 17 years old, 124 schoolteachers and a group of 55 mothers. The educational approach was implemented for 18 months and consisted of reinforcements of interventions addressed to students and schoolteachers at school level and few activities targeted at the mothers, performed by means of home visits. Baseline and follow-up interviews focused on oral health care were undertaken for the entire study population. As a stimulus for the students to achieve proper oral hygiene habits, the simplified oral hygiene index was assessed at three different moments. A statistically significant improvement in their oral hygiene index $(p<0.001)$ was recorded. The results achieved suggest an encouraging tendency towards the improvement in the levels of oral health care among the school-age youths studied. They also point out the need of intensifying the preparation of schoolteachers in oral health topics, as well the instructions to the mothers for their oral health care. Moreover, they highlight the importance of the continuous implementation of school-based programs to promote the oral health.
\end{abstract}

UNITERMS: Dental education; Health promotion; Oral care; Schoolchildren; Adolescents; Mothers; Schoolteachers.

\section{INTRODUCTION}

Oral health educational programs have been considered as an important and integral part of many oral health policies for a long time. Traditionally, they tended to focus too much on oral diseases prevention through health enhancement and voluntary changes in behavior as a consequence of learning opportunities ${ }^{8}$.

Over the last few years, dentists are gradually becoming aware of the health promotion principles, a new philosophy that emerged opposed to the traditional, dominant, curative and "high-tech" model of health practices. Their strategies aim at reducing differences in the current health status and ensuring equal opportunities and resources to enable all people to achieve their fullest health potential ${ }^{1}$. Henceforth, health educational interventions began to be focused as a core component of those health promotion strategies.

Thus, in the field of Dentistry, health education actions should address the process of enabling people to increase control over and to improve their patterns of oral health by providing them with knowledge concerning the prevailing oral health problems and methods for their prevention and control, besides providing them with the skills, social support, and environmental reinforcement they need to adopt long-term healthy behaviors ${ }^{7}$.

According to Brown ${ }^{2}$, the research in health education and health promotion has expanded rapidly over the past two decades, while the latter has been increasingly recognised as a factor to meet public health objectives and to improve the success of public health interventions. Many 
studies focused on items related to oral health education and promotion were presented during the $5^{\text {th }}, 6^{\text {th }}$ and $7^{\text {th }}$ World Congresses on Preventive Dentistry, sponsored chiefly by the World Health Organization, and can illustrate this fact ${ }^{22-24}$.

By searching on current publication, it can be identified that previous studies focusing on school-based oral health education were primarily concerned with the relationship between the oral health status and the pattern of oral health knowledge and behavior in schoolchildren ${ }^{3,9,13,15,20}$. Besides dealing with this relationship, others have assessed the oral health knowledge, attitudes and practices of the schoolchildren's mothers ${ }^{16,21}$. Moreover, studies including the assessment of the schoolteachers' knowledge and attitudes with regard to oral health education of children were also carried out ${ }^{12,14}$.

Despite the professional awareness on the subject, McDonald and Avery ${ }^{11}$, pointed out that although most schools encourage health programs, very few provide the proper value to oral health educational interventions. The authors also highlighted that the programs in almost all schools are usually condensed and fail to consider several important aspects required to improve the oral health habits.

Concerned with the questions above and the fact that no long-term oral health educational intervention had yet been developed in the public primary schools of Maringa, Brazil, Conrado ${ }^{4}$ undertook a pilot study in four of those schools, applying a different health education strategy for each. One of the four methodologies applied yielded better results than the other three in terms of improving the children's knowledge and behaviour on oral health.

Due to such significant results and aiming at extending similar benefits to school-age youths regularly attending all public schools of the city of Maringa-PR, the main purpose of the present investigation was to evaluate the preliminary results of a school-based oral health educational strategy, based on the same methodology that proved to be the best in that previous study, adopted at public primary schools of the city of Maringa, State of Parana, Brazil.

\section{METHODS}

The study population comprised schoolchildren, adolescents and schoolteachers from a total of 29 public primary schools of the city of Maringa, State of Parana, Brazil. Information about all schools such as their addresses and total number of students in each unit by age was obtained from the local authorities. After consulting the Statistics Department of the State University of Maringa, a random sampling technique was applied and 556 students (10\% of the total number) ranging from 6 to 17 years old were selected. Consent letters were delivered to the parents and all 124 schoolteachers employed in the city were invited to participate. Further, 55 mothers (10\% of the students sample) were randomly selected and invited to take part in the study.

The oral health educational strategy was started by activities during three semesters (18 months), as follows:

\section{Activities at the first semester}

Baseline interviews with students and teachers were undertaken by 5 undergraduate and 3 postgraduate dental students and one dental hygienist, who were previously trained and calibrated. A structured questionnaire developed by Todescan and Sima ${ }^{19}$ was adapted for this study, which included sociodemographic characteristics and information on the students' knowledge on oral health care, source of information, reasons for oral hygiene; their oral health care practices: oral hygiene habits (tooth brushing, use of dentifrice, flossing) and use of professional dental services (dental visits and professional fluoride application). A similar protocol was designed to interview the students' mothers and teachers.

Undergraduate and postgraduate dental students under the supervision of two dental professors carried out the educational approach. This comprised: schoolteachers' introduction to oral health-related topics involving six courses (healthy oral conditions, common oral problems: tooth decay and gum disease, oral health preventive procedures: oral hygiene, dietary advices, fluoride use in life stages and dental visits and treatments); appropriate instructions for the school-age youths through monthly educational sessions (basic oral health information as the value of good oral health, tooth and gum care, proper oral hygiene, fluoride use, dietary advices and dental visits); and family involvement through home visits at the youths' mothers every three months. The teaching material consisted mainly of slides, transparencies, posters, banners, videos, study models, information leaflets, specific books and magazines. Taking into account the differences in age and educational level, different techniques were adopted to stimulate participation, such as puppet shows, songs, plays, hand out activity sheets such as word searches and quizzes, individual counselling, small group work, and outreach activities.

As a stimulus for the students to assume their own oral hygiene habits, dental plaque accumulation was assessed using the simplified oral hygiene index proposed by Greene and Vermillion and modified by Greene ${ }^{6}$. The dental students and dental hygienist who had been previously trained and calibrated carried out the clinical examinations.

\section{Activities at the second semester}

Reinforcements on the educational actions were undertaken with the students. The second examination of their oral hygiene status was conducted.

Activities at the third semester: These consisted of continuous reinforcements of the previous educational actions and accomplishment of follow-up interviews using the same questionnaire applied at baseline to provide valid comparisons over the period. The students' third oral hygiene index assessment was performed.

Data were analysed by the Statistical Program of Social 
Science (SPSS). Descriptive statistics and the " $\mathrm{t}$ " test were used when appropriate. Statistical significance was taken at the $5 \%$ level.

\section{RESULTS}

A total of 503 children and adolescents (response rate, 90.5\%; 51.4\% boys, 48.6\% girls), 108 schoolteachers (response rate, $87.0 \%)$ and all mothers $(\mathrm{N}=55)$ completed the study. When comparing the school-age youths' responses at the baseline interviews with the follow-up, important improvements on their oral health practices could be noticed. For example, there was an important decrease in the percentage of those reporting that they had never visited a dentist (13.4\% ${ }^{\circledR 5.6 \%)}$ ) and among those that stated doing it only when facing pain $(29.4 \% \AA 13.9 \%)$. There was also an increase in the proportion of those children and adolescents claiming to brush their teeth three or more times a day (51.2\% $\%$ 83.1\%), using dentifrice (62.2\%®89.7\%), flossing (30.9\% ${ }^{\circledR 50.5 \%)}$ and having received a professional fluoride application (24.5\%®40.2\%). Despite of the persistence of a group who did not specify the frequency $(12.8 \AA 5.0)$, all students reported toothbrushing habit (Table 1).

At both baseline and follow-up interviews, the children

TABLE 1- Oral health practices among children and adolescents of public schools in Maringa, Brazil, at baseline ( $N=556)$ and at follow-up interviews ( $\mathrm{N}=503)$

\begin{tabular}{|c|c|c|c|c|}
\hline \multirow[t]{2}{*}{ Practices } & \multicolumn{2}{|c|}{ Baseline } & \multicolumn{2}{|c|}{ Follow-up } \\
\hline & $\mathrm{N}$ & $\%$ & $\mathrm{~N}$ & $\%$ \\
\hline \multicolumn{5}{|c|}{ Frequency of dental visits } \\
\hline Never been to & 75 & 13.40 & 28 & 5.57 \\
\hline Once a year & 149 & 26.81 & 203 & 40.36 \\
\hline Twice a year & 91 & 16.41 & 114 & 22.66 \\
\hline Three times a year & 28 & 4.97 & 39 & 7.75 \\
\hline Facing pain & 163 & 29.37 & 70 & 13.92 \\
\hline No answer & 50 & 9.04 & 49 & 9.74 \\
\hline
\end{tabular}

Use of dentifrice

Yes

No

Twice

Three times

Four times and more

No answer

71

Flossing

Yes

No

Professional fluoride application 
and adolescents pointed out some preventive oral health resources and reasons for oral hygiene procedures. A relatively high proportion of sensible answers was obtained by the end of the study, when, besides oral hygiene, more students included diet control, fluoride use and regular dental visiting, as examples of proper habits on the way to oral health promotion. The reasons mentioned to have good oral hygiene habits also improved (Table 2). With regard to the main source of information on oral healthy behaviors, mothers were mentioned by $54.4 \%$ of the children and adolescents.

Findings on the mothers' oral health behaviors were outstanding, whereas the schoolteachers were expected at the baseline investigation. Mothers demonstrated poor oral health habits during the first visits to selected homes, and although all of them reported a toothbrushing habit, 5\% of them did not use dentifrice. Moreover, $78.2 \%$ of them reported not having the habit of flossing and $80 \%$ assumed that they had never received professional fluoride application. An improvement in mothers' practices could be detected at the follow-up interviews (Table 3), although less evident than the improvement observed in the students' sample.

Comparing the three oral hygiene scores (Table 4), from
0 to 3 scale ( $0=$ excellent and $3=$ very poor oral hygiene), there was statistically significant $(\mathrm{p}<0.001)$ dental plaque reduction among children and adolescents.

\section{DISCUSSION}

The results of the present long-term oral health educational strategy demonstrated some positive impacts for the target population as a whole, despite the different levels.

A statistically significant reduction in the students' dental plaque scores was reached in the present study, in disagreement with an investigation conducted in Tanzania ${ }^{20}$, which showed that a school-based oral health educational program implemented did not result in significant reductions of the plaque scores. The changes observed on the figures of the simplified oral hygiene index might express an important improvement in the children's and adolescents' skills to control dental plaque accumulation, one of the essential biological factors associated with the development of the most prevalent oral diseases. However, these findings should not be considered directly linked to the educational oral health strategy adopted, as no control group was selected for comparison. This fact may be regarded as one of the limitations of the study.

TABLE 2- Knowledge about oral health care among children and adolescents of public schools in Maringa, Brazil, at baseline $(\mathrm{N}=556)$ and at follow-up interviews $(\mathrm{N}=503)$

\begin{tabular}{lccc}
\hline Knowledge & Baseline* $^{*}$ & Follow-up* $^{*}$ \\
\hline & $\mathrm{N}$ & $\%$ & $\mathrm{~N}$ \\
\hline
\end{tabular}

Preventive oral health resources

\begin{tabular}{|c|c|c|c|c|}
\hline Dietary control & 119 & 21.5 & 162 & 32.2 \\
\hline Toothbrushing & 556 & 100.0 & 503 & 100.0 \\
\hline Toothpaste & 346 & 62.2 & 451 & 89.7 \\
\hline Dental floss & 171 & 30.8 & 254 & 50.5 \\
\hline Fluoride application & 138 & 24.6 & 202 & 40.1 \\
\hline Dental visits & 17 & 3.0 & 53 & 10.5 \\
\hline \multicolumn{5}{|c|}{ Reasons for oral hygiene procedures } \\
\hline Tooth cleanliness & 202 & 36.4 & 176 & 35.0 \\
\hline Avoid caries & 83 & 14.9 & 142 & 28.2 \\
\hline Avoid tooth rotten & 15 & 2.7 & 33 & 6.6 \\
\hline Block carious process & 202 & 36.3 & 117 & 23.2 \\
\hline Avoid bad breath & 11 & 2.0 & 78 & 15.5 \\
\hline Others & 53 & 9.6 & 61 & 12.1 \\
\hline Do not know & 27 & 5.0 & 19 & 3.8 \\
\hline
\end{tabular}

* Considering that each student pointed out one or more resources and procedures. 
Previous research has pointed out that changes in oral health knowledge and behavior can be significant at the population level, especially among young groups ${ }^{7}$. In accordance, better results were achieved within the group of children and adolescents along the period of the present study. Their patterns of oral health practices had improved as demonstrated by the higher proportion of individuals adopting preventive dental visits, regular daily toothbrushing, proper dental flossing practices and professional application of fluoride. In addition, at the follow-up interviews, even though it may be considered a subjective observation, the responses of many children and teenagers that implemented the strategy expressed an increase in the awareness on the importance of good practices for oral health promotion.

Part of the success obtained through the educational actions developed among the young group might also be assigned to the pedagogical methods and resources adopted. The assumption was that the best way of imparting knowledge consisted of lectures and other methods, mainly through puppet shows, plays and songs. The recommendation for the utilization of an "entertaining, easy to understand and practical” educational material in an oral

TABLE 3 - Oral health practices among schoolteachers $(\mathrm{N}=108)$ and mothers $(\mathrm{N}=55)$ of the schoolchildren of public schools in Maringa, Brazil, at baseline and at follow-up interviews

\begin{tabular}{|c|c|c|c|c|}
\hline \multirow[t]{2}{*}{ Oral health practices } & \multicolumn{2}{|c|}{ Schoolteachers } & \multicolumn{2}{|c|}{ Mothers } \\
\hline & Baseline & Follow-up & Baseline & Follow-up \\
\hline & N (\%) & N (\%) & N (\%) & N (\%) \\
\hline \multicolumn{5}{|l|}{ Use of dentifrice } \\
\hline Yes & $108(100)$ & $108(100)$ & $52(95)$ & $55(100)$ \\
\hline No & - & - & $03(5.4)$ & - \\
\hline \multicolumn{5}{|c|}{ Daily toothbrushing habit } \\
\hline Twice & - & - & $26(48)$ & $15(28)$ \\
\hline Three times & $86(80)$ & $81(75)$ & $25(45)$ & $33(59)$ \\
\hline Four times & $22(20)$ & $27(25)$ & $04(7)$ & $07(13)$ \\
\hline \multicolumn{5}{|l|}{ Flossing } \\
\hline Yes & $92(85)$ & $104(96)$ & $12(21.8)$ & $31(56.4)$ \\
\hline No & $16(14.8)$ & $04(3.7)$ & $43(78.2)$ & $24(43.6)$ \\
\hline \multicolumn{5}{|c|}{ Professional Fluoride application } \\
\hline Yes & $58(54)$ & $71(65.7)$ & $11(20)$ & $21(38)$ \\
\hline No & $50(46.3)$ & $37(34.3)$ & $44(80)$ & $34(62)$ \\
\hline
\end{tabular}

TABLE 4- Relationship among the three readings of the simplified oral hygiene index examinations on children and adolescents of public schools of Maringa, Brazil. $(\mathrm{N}=503)$

\section{Simplified oral hygiene index}

\begin{tabular}{llll}
\hline Readings & Mean & SD & t value \\
\hline $1^{\text {st }}$ & 2.55 & 0.36 & $181.282^{\star}$ \\
$2^{\text {nd }}$ & 1.35 & 0.16 & $218.326^{\star}$ \\
$3^{\text {rd }}$ & 0.87 & 0.13 & $175.048^{*}$ \\
\hline
\end{tabular}


health program had also been previously reported ${ }^{18}$. Moreover, the methodology adopted was in agreement with the recommendation that closely supervised teaching on a multiple-visit basis and periodic reinforcements are the best approach to change behavior ${ }^{10}$.

Nevertheless, the satisfactory responses obtained should be carefully interpreted. The conclusions reached by Brown ${ }^{2}$ on a comprehensive review of 57 studies suggested that oral health education may result in improvements in the objective measures of oral health behavior and actual oral health measures, but has only limited success in changing attitudes towards oral issues and achieves only short-term gains in knowledge. Furthermore, the influence of social and political factors as key determinants of health as mentioned by Sheiham, Watt ${ }^{17}$ and cultural factors on oral health practices as stated by Mathewson, Primosch ${ }^{10}$ must also be considered.

With regard to home visits, the results did not match those found at schools. Even so, a mild improvement in the mothers' behavior was recorded at the end of the study. Some factors may explain this fact. It should be mentioned that certain mothers were unwilling to participate in the program and others were somewhat indifferent. Moreover, the small sample size and the low number of home visits (twice during the first semester) should also be considered.

Considering the high proportions of individuals participating in the present study that mentioned their own mothers as the main source of oral health information, and taking into account that the current Brazilian health policies ${ }^{5}$ are focusing their efforts on the family health strategy, special attention should be given to children's and adolescents' mothers when planning further educational programs. Beside, working in a multidisciplinary team should undoubtedly be considered for the achievement of better results.

A new approach to health promotion launched as a tripartite project by the WHO Regional Office for Europe, the European Commission and the Council of Europe ${ }^{25}$ is of paramount interest. It was set up to establish a group of model schools that would demonstrate the impact of health promotion at school environment. The schools involved in the project would then disseminate their experience and information to the health and educational sectors, influencing the policies and practices in school health promotion at the national and international levels. The basis of its success is the integration of health promotion in all aspects of the school daily routine. Thus, health promotion becomes an essential component of all curriculum activities, since the curriculum is structured to enable the students to review aspects of health in variable and innovative ways throughout their school careers.

\section{CONCLUSION}

In conclusion, this study has arisen from the idea of providing a low-cost and long-term oral health educational program for all public schools of Maringa, in an attempt to replace the short-term programs widely used in Brazil. Even though some aspects of the strategy adopted must be re- thought, the results achieved suggest an encouraging tendency towards an improvement in the levels of oral health care among the school-age youths studied. They point out the need of intensifying the preparation of schoolteachers in oral health topics, as well the mothers' instructions for their oral health care. Moreover, they highlight the importance of the continuous implementation of schoolbased programs in order to promote oral health, trying to spread the word on good oral health care to as many people as possible.

\section{RESUMO}

O principal propósito deste estudo foi avaliar os resultados preliminares de uma estratégia educacional baseada em escolas sobre saúde bucal adotada em escolas públicas de ensino fundamental da cidade de Maringá, estado do Paraná, Brasil. A amostra de estudo foi composta por 556 crianças e adolescentes entre 6 e 17 anos de idade, 124 professoras e um grupo de 55 mães. A abordagem educacional foi implementada por um período de 18 meses e consistiu de reforços das intervenções educativas dirigidas aos estudantes e professores a nível escolar e de poucas atividades tendo como alvo as mães, desenvolvidas através de visitas domiciliares. Entrevistas iniciais e de acompanhamento focando cuidados em saúde bucal foram realizadas com toda a população de estudo. Como um estímulo aos estudantes para assumirem hábitos apropriados de higiene bucal, o índice de higiene oral simplificado foi avaliado em três diferentes momentos. Uma melhora estatisticamente significante em seus índices de higiene oral $(\mathrm{p}<0,001)$ foi registrada. Os resultados alcançados sugerem uma encorajadora tendência de melhoria nos níveis de cuidados em saúde bucal entre os jovens em idade escolar estudados. Eles, também, apontam para a necessidade de se intensificar o preparo das professoras em tópicos relacionados à saúde bucal, bem como a instrução das mães para os cuidados apropriados com a saúde bucal. Além disso, eles evidenciam a importância da contínua implementação de programas baseados em escolas para a promoção da saúde bucal.

UNITERMOS: Educação em Odontologia; Promoção da saúde; Cuidados bucais; Escolares; Adolescentes; Mães; Professores.

\section{ACKNOWLEDGEMENTS}

The authors would like to thank the National Council for Research (CNPq) of the Brazilian Ministry of Science and Technology, the Special Training Program (PET) of the Brazilian Ministry of Education and the State University of Maringá for a fellowship research awarded to the main author and scholarships to graduate and undergraduate students Márcia Regina de Oliveira, Juliana Manganoti Negro, Magda Occhi Gonzaga, Marcelo Tavares Roque, Ernesto Yukihiro 
Miyamoto, Newman da Silva Gomes Jr., Renato Afonso Verri and Marco Antonio Demite. All of them were being of great help during the study. The authors would also like to thank the local authorities of Maringá for their special contribution to the project.

\section{REFERENCES}

1- Brasil. Ministério da Saúde. Projeto Promoção da Saúde. Brasília: Ministério da Saúde; 2001. 112p.

2- Brown LF. Research in dental health education and health promotion: a review of the literature. Health Education Quarterly 1994; 21: 83-102.

3- Buischi Y, Axelsson P, Oliveira L, Mayer M, Gjermo P. Effect of two preventive programs on oral health knowledge and habits among Brazilian schoolchildren. Community Dent Oral Epidemiol 1994; 22: 41-6.

4- Conrado CA. Efeito de um programa educacional direto relacionado com a Saúde bucal de escolares do município de Maringá-PR. I: estudos preliminares. Rev Odontol Clínica 1997; 7:17-26.

5- Costa ICC. Investindo na promoção de saúde: programas de saúde da família e Agentes comunitários de saúde. Uma análise de suas performances em oito municípios brasileiros. Rev ABOPREV 1998; $1: 30-7$.

6- Greene JC. The oral hygiene index: development and use. J Periodontol 1967; 38: 625-35.

7- Guidelines for school health programs to promote lifelong healthy eating. Centre for Disease Control and Prevention. MMWR Morb Mortal Wkly Rep 1996 un 14; 45(RR-9): 1-41.

8- Kay EJ, Locker D. Is dental health education effective? A systematic review of current evidence. Community Dent Oral Epidemiol 1996; 24: 231-5.

9- Kinnby CG et al. Evaluation of information on dental health care at child health centers. Acta Odontol Scand 1991; 49: 289-99.

10- Mathewson RJ, Primosch RE. Fundamentals of Pediatric Dentistry. Chicago: Quintessence Books; 1995.

11- McDonald RE, Avery DR. Dentistry for the child and adolescent. 6th Ed. St. Louis: Mosby; 1994.

12- Nyandindi U, Palin-Palokas T, Milen A, Robinson V, Kombe N, Mwakasagule S. Participation, willingness and abilities of schoolteachers in oral health education in Tanzania. Community Dent Health 1994; 11: 101-4.

13- Peng B, Petersen PE, Fan MW, Tai BJ. Oral health status and oral health behavior of 12-year-old urban schoolchildren in the People's Republic of China. Community Dent Health 1997; 14: 238-44.

14- Petersen PE, Mzee MO. Oral health profile of schoolchildren, mothers and schoolteachers in Zanzibar. Community Dent Health 1998; 15: 256-62.
15- Petersen PE. Oral health behavior of 6 year-old Danish children. Acta Odontol Scand 1992; 50: 57-64.

16- Raymer RN, Gift, HC. Contributing factors to maternal and child oral health. J Public Health Dent 1991; 50: 370-8.

17- Sheiham A, Watt RG. The common risk factor approach: a rational basis for promoting oral health. Community Dent Oral Epidemiol 2000; 28: 399-406.

18- Silveira EG, Silva RHH, Almeida ICS. Uma metodologia para um programa educativo-preventivo em saúde bucal para escolares. Rev Assoc Paul Cir Dent 1998; 20: 8-12.

19- Todescan JH, SIMAFT. Campanhas de prevenção e orientação para com a Higiene bucal-I. Rev Assoc Paul Cir Dent 1991; 45:5379

20- Van Palenstein Helderman WH, Munck L, Mushendwa S, van't Hof MA, Mrema FG. Effect evaluation of an oral health education programme in primary schools in Tanzania. Community Dent Oral Epidemiol 1997; 25: 296-300.

21- Vigild M, Petersen PE, Hadi R. Oral health behavior of 12year-old children in Kuwait. Int J Paediatric Dent 1999; 9: 23-9.

22- World Health Organisation. 5th World Congress on Preventive Dentistry; Official Programme: WHO, Technical Reports Series: São Paulo, Brazil, 1995

23- World Health Organisation. 6th World Congress on Preventive Dentistry; Official Programme: WHO, Technical Reports Series: CapeTown, South Africa, 1997.

24- World Health Organisation. 7th World Congress on Preventive Dentistry; Official Programme: WHO, Technical Reports Series: Beijing, China, 2000.

25- World Health Organisation Regional Office for Europe, European Commission and Council of Europe. Introduction to the European network of health promoting schools. WHO, public. 1999.

Recebido para publicação em: 16/06/2003

Enviado para reformulações em: 06/08/2003

Pronto para publicação em: 02/10/2003

Correspondence to:

Prof. Dr. Carlos Alberto Conrado

Departamento de Odontologia - Universidade Estadual de Maringá

Clínica Odontológica da UEM - Av. Mandacaru, 1550 - Bloco

S08

CEP 87.080-000 - Maringá - PR - Brazil

Telephone and fax: 0055-44-224-3633

e-mail: caconrado@wnet.com.br 